\title{
Konflik peran kerja-keluarga pada ibu bekerja terhadap perilaku obesogenis anak sekolah dasar
}

\author{
Work-family conflict in working mothers to obesogenic behaviors of elementary school children
}

Almira Sitasari ${ }^{1}$, Madarina Julia ${ }^{2}$, Toto Sudargo ${ }^{3}$

\begin{abstract}
Background: Childbearing pattern of parents greatly affects healthy lifestyle of children including behaviors preventing children from obesity. Working mothers with dual role at work and the family face challenges in doing so. Objective: To identify effect of work-family conflict in working mothers to obesogenic behaviors of elementary school children at Yogyakarta Municipality. Method: This was a quantitative study with cross sectional design. Obesogenic behaviors was assessed using questionnaire of Family Health Behavior Scale. Role conflict was assessed using questionnaire of Work-Family Conflict filled by working mothers. Nutrition status of children was assessed using parameter of body mass index by age with standard of WHO 2007. Results: The result of the study showed $47.73 \%$ of working mothers had high role conflict and $45.26 \%$ of children had high obesogenic behaviors. There was no effect of work-family conflict in working mothers to obesogenic behaviors of elementary school children at Yogyakarta. The influencing factors were family income ( $<<0.001)$; position/job type $(p<0.001)$; gender ( $p<0.05)$; and nutrition status ( $<<0.05)$. Conclusion: Work-family conflict in working mothers had no effect to obesogenic behaviors of elementary school children at Yogyakarta Municipality.
\end{abstract}

KEY WORDS: role conflict, working mothers, obesogenic behaviors, school children

\begin{abstract}
ABSTRAK
Latar belakang: Pola asuh orang tua sangat mempengaruhi perilaku hidup sehat anak termasuk perilaku yang menghindarkan anak dari obesitas. Ibu bekerja yang memiliki peran ganda dalam pekerjaan dan keluarga memiliki tantangan dalam melakukan hal ini. Tujuan: Mengetahui pengaruh konflik peran kerja-keluarga pada ibu bekerja dengan perilaku obesogenis anak-anak sekolah dasar di Kota Yogyakarta. Metode: Studi potong lintang dengan pendekatan kuantitatif. Perilaku obesogenis diketahui menggunakan kuesioner Family Health Behaviour Scale dan konflik peran kerja diketahui dengan menggunakan kuesioner WorkFamily Conflict yang diisi oleh ibu bekerja. Status gizi anak diukur menggunakan parameter indeks BMI/U dengan standar WHO 2007. Hasil: Terdapat $47,72 \%$ ibu bekerja dengan konflik peran tinggi dan $45,26 \%$ anak dengan perilaku obesogenis tinggi. Tidak ada pengaruh konflik peran kerja-keluarga pada ibu bekerja terhadap perilaku obesogenis anak sekolah dasar di Yogyakarta. Hal yang mempengaruhinya antara lain adalah pendapatan keluarga $(\mathrm{p}<0,001)$; posisi/jenis pekerjaan ibu $(\mathrm{p}<0,001)$; jenis kelamin $(\mathrm{p}<0,05)$; dan status gizi $(\mathrm{p}<0,05)$. Simpulan: Konflik peran kerja-keluarga pada ibu bekerja tidak memiliki pengaruh terhadap perilaku obesogenis anak sekolah dasar di Kota Yogyakarta.
\end{abstract}

KATA KUNCI: konflik peran, ibu bekerja, perilaku obesogenis, anak

\section{PENDAHULUAN}

Obesitas di Indonesia telah menjadi masalah yang serius (1), tidak terkecuali pada kelompok umur anakanak. Di Daerah Istimewa Yogyakarta (DIY), angka prevalensi gizi lebih di satu kabupaten telah melebihi angka nasional sedangkan di Kota Yogyakarta, angkanya mendekati angka nasional (2). Orang tua sangat berperan secara signifikan dalam perkembangan pola hidup sehat pada anak dan remaja (3). Ibu yang bekerja tentu akan menghadapi tantangan yang lebih besar dibandingkan ibu yang tidak bekerja dalam memenuhi peran ini karena adanya 'peran ganda' yang disandangnya, yaitu sebagai orang tua dan wanita karir. Beberapa penelitian di negara maju menunjukkan adanya hubungan antara status ibu

\footnotetext{
Korespondensi: Jurusan Gizi, Politeknik Kesehatan Kementerian Kesehatan Yogyakarta, Jl. Tata Bumi No. 3 Banyuraden Gamping, Sleman, Yogyakarta, e-mail: almira.sita@gmail.com

Bagian Ilmu Kesehatan Anak, Rumah Sakit Umum Pusat Dr. Sardjito/Fakultas Kedokteran Universitas Gadjah Mada, Jl.Kesehatan No. 1 Yogyakarta, e-mail: madarinajulia@yahoo.com

3 Program Studi Gizi Kesehatan, Fakultas Kedokteran Universitas Gadjah Mada, J1. Farmako, Sekip Utara, Yogyakarta 55281,e-mail: toto_sudargo@yahoo.
} co.id 
bekerja (4) dan waktu kerja ibu (5) dengan obesitas pada anak, tetapi hal ini masih menjadi perdebatan di negaranegara Asia mengingat sebab dan kelompok yang rawan terhadap kejadian obesitas di negara berkembang sangat bervariasi $(6,7)$.

Pada era industrialisasi, faktor obesogenis seperti tingginya perkembangan industri makanan cepat saji lokal maupun nonlokal dan penggunaan berbagai macam barang elektronik yang mengurangi aktivitas fisik, banyak ditemui dan semakin dekat dengan anak-anak di kota besar termasuk di Yogyakarta. Oleh karena itu, diperlukan studi yang mempelajari pengaruh konflik peran kerjakeluarga pada ibu bekerja terhadap perilaku obesogenis anak-anak sekolah dasar di Kota Yogyakarta.

\section{BAHAN DAN METODE}

Jenis penelitian ini adalah penelitian observasional dengan rancangan potong lintang. Penelitian dilaksanakan di delapan sekolah dasar negeri dan swasta non fullday di Kota Yogyakarta pada April-Juni 2012. Kriteria inklusi anak adalah tidak sedang menjalani diit penyakit dan bukan penganut vegetarianisme sedangkan kriteria inklusi ibu bekerja adalah pernah menamatkan SMA/sederajat; berusia minimal 20 tahun; bekerja di luar rumah lebih dari 20 jam per minggu; sehari-hari tinggal bersama anak; dan juga bukan penganut vegetarianisme. Perhitungan besar sampel berdasarkan rumus uji populasi satu sampel (8) menggunakan perangkat lunak penghitung sampel S-Size dengan tingkat kepercayaan 95\%; tingkat kekuatan uji sebesar $80 \%$; proporsi kebiasaan konsumsi makanan cepat saji anak yang tinggi pada ibu yang bekerja secara penuh sebesar $43,7 \%$ (Po); dan proporsi kebiasaan konsumsi makanan cepat saji anak yang tinggi pada ibu yang bekerja secara paruh waktu sebesar 36,1\% (Pa) (9) sehingga diperoleh sampel minimal penelitian sebesar 260 orang. Sampel untuk penelitian ini ditentukan dengan cara simple random sampling. Sebanyak 285 pasangan ibu bekerja dan anak memenuhi kriteria untuk ikut dalam penelitian ini.

Karakteristik responden antara lain pendidikan ibu yang dibedakan menjadi dua kategori yaitu menengah (tamat SMA) dan tinggi (tamat akademi/perguruan tinggi); kedudukan ibu dalam pekerjaan (teknis atau profesional/manajerial); lama bekerja ibu dalam sehari dikategorikan menjadi intensitas rendah jika bekerja 5-7 jam per hari, intensitas sedang jika bekerja 8-12 jam per hari, dan intensitas tinggi jika bekerja lebih dari 12 jam per hari; pendapatan keluarga; serta persentase pendapatan ibu terhadap seluruh pendapatan keluarga ( $\geq 50 \%$ dari seluruh pendapatan keluarga atau $<50 \%$ dari seluruh pendapatan keluarga). Pendapatan keluarga diperoleh dari upah minimum Provinsi DIY tahun 2011 (Rp 808.000,00) dikalikan 3-4 orang anggota dalam keluarga dengan asumsi mencukupi kebutuhan seharihari dan dibedakan menjadi dua kategori yaitu rendah $(<$ Rp 4.000.000,00/bulan) dan tinggi ( $\geq$ Rp 4.000.000,00/ bulan).

Perilaku obesogenis sebagai variabel dependen dinilai dengan kuesioner perilaku sehat keluarga (Family Health Behaviour Scale), terdiri dari 4 subskala yang secara keseluruhan dapat mengukur perilaku sehat keluarga, perilaku obesogenis, rutinitas perilaku makan, dan kebiasaan aktivitas fisik keluarga sehingga mampu menilai perilaku makan dan aktivitas fisik dalam keluarga yang berhubungan dengan obesitas pada anak (10). Sementara itu, konflik peran kerja dan keluarga pada ibu bekerja sebagai variabel independen dinilai dengan kuesioner konflik multi peran (work-family conflict) (11). Adopsi kuesioner dilakukan dengan cross-cultural adaptation test lalu dicobakan pada 20 responden untuk mengetahui pemahaman isi kuesioner. Kuesioner jadi kemudian dikirimkan pada ibu untuk diisi secara mandiri. Variabel luar dan variabel pengganggu potensial juga diteliti. Variabel luar meliputi jenis pekerjaan; jumlah anak; lama bekerja; dan status gizi anak sedangkan variabel pengganggu potensial meliputi struktur keluarga (keluarga inti atau keluarga besar); status pekerjaan ayah (jika ibu bukan sebagai orang tua tunggal); pendapatan keluarga; persentase pendapatan ibu; keberadaan asisten rumah tangga; dan preferensi makanan keluarga yaitu jenis makanan yang dimakan keluarga sehari-hari, biasanya disesuaikan dengan keyakinan agama yang dianut (halal atau tidak berpantang).

Perilaku obesogenis adalah perilaku-perilaku yang berhubungan atau memperbesar faktor risiko terjadinya kelebihan gizi dan obesitas pada anak yang dinilai dengan kuesioner perilaku sehat keluarga (10). Kuesioner terdiri 
dari 28 pernyataan yang diberikan skor 0 (mengindikasikan tidak setuju) sampai 3 (mengindikasikan sangat setuju) dengan skala likert 4 poin yang kemudian dijumlahkan sebagai skor. Hasil skor dikelompokkan dalam dua kategori yaitu perilaku obesogenis tinggi (skor $<$ median skor yang didapat setelah survei) dan perilaku obesogenis rendah (skor $\geq$ median skor yang didapat setelah survei). Konflik peran kerja dan keluarga adalah tipe konflik multiperan pada ibu bekerja yaitu domain peran dalam pekerjaan tidak sesuai dengan tuntutan peran dari domain keluarga (11). Kuesioner terdiri dari 5 pernyataan yang diberikan skor 0 (mengindikasikan tidak pernah) sampai 3 (mengindikasikan selalu) dengan skala likert 4 poin yang kemudian dijumlahkan dalam skor. Hasil skor dikelompokkan dalam dua kategori yaitu konflik multiperan tinggi (skor $\geq$ median skor yang didapat setelah survei) dan konflik multiperan rendah (skor $<$ median skor yang didapat setelah survei).

Status gizi anak diukur dengan parameter indeks massa tubuh per umur (IMT/U) menurut referensi World Health Organization (WHO) 2007 dan dianalisis dengan software WHO Anthroplus for Stata 12. Kategori status gizi yang digunakan adalah status gizi kurus-normal $(\mathrm{IMT} / \mathrm{U} \leq+1 \mathrm{SD})$, status gizi lebih (IMT/U $>+1 \mathrm{SD}$ sampai dengan $\leq+2 \mathrm{SD}$ ), dan status gizi obesitas (IMT/U $>+2$ SD) (12). Microtoise digunakan untuk mengukur tinggi badan anak dan timbangan berat badan digital untuk mengukur berat badan anak.

Pengolahan data dilakukan secara univariat (frekuensi dan persentase), bivariat (Chi-Square), dan multivariat (regresi linier ganda). Etika penelitian (ethical clearance) sudah diperoleh dari Komisi Etik Fakultas Kedokteran Universitas Gadjah Mada dengan nomor $\mathrm{KE} / \mathrm{FK} / 280 / \mathrm{EC}$.

\section{HASIL}

Sebanyak 285 anak menjadi subjek penelitian ini dengan rerata umur anak yaitu 8,8 tahun. Terdapat 20,35\% subjek penelitian berstatus gizi obesitas. Sebagian besar ibu dari subjek penelitian berpendidikan tinggi $(67,72 \%)$ dan bekerja dengan posisi sebagai profesional atau manajerial $(62,81 \%)$ di luar lingkungan tempat tinggalnya (91,58\%). Lama bekerja sebagian besar ibu responden adalah lebih dari atau sama dengan 8 jam per hari $(61,05 \%)$ dengan penghasilan $50,88 \%$ ibu yang menyumbang lebih dari setengah pendapatan keluarga (Tabel 1).

Tabel 1. Karakteristik subjek penelitian $(n=285)$

\begin{tabular}{|c|c|c|}
\hline Karakteristik anak & $\mathbf{n}$ & $\%$ \\
\hline \multicolumn{3}{|l|}{ Jenis kelamin } \\
\hline Laki-laki & 132 & 46,32 \\
\hline Perempuan & 153 & 53,68 \\
\hline \multicolumn{3}{|l|}{ Jumlah saudara } \\
\hline 3 atau lebih & 22 & 7,72 \\
\hline 2 & 70 & 24,56 \\
\hline 1 atau kurang & 193 & 67,72 \\
\hline \multicolumn{3}{|l|}{ Status gizi } \\
\hline Kurus & 53 & 18,60 \\
\hline Normal & 121 & 42,46 \\
\hline Lebih & 53 & 18,60 \\
\hline Obesitas & 58 & 20,35 \\
\hline Karakteristik orang tua & $\mathbf{n}$ & $\%$ \\
\hline \multicolumn{3}{|l|}{ Pendidikan ibu } \\
\hline Menengah & 92 & 32,28 \\
\hline Tinggi & 193 & 67,72 \\
\hline \multicolumn{3}{|l|}{ Posisi pekerjaan ibu } \\
\hline Teknis & 106 & 37,19 \\
\hline Profesional/manajerial & 179 & 62,81 \\
\hline \multicolumn{3}{|l|}{ Tempat bekerja ibu } \\
\hline Dalam rumah & 24 & 8,42 \\
\hline Luar rumah & 261 & 91,58 \\
\hline \multicolumn{3}{|l|}{ Lama bekerja ibu } \\
\hline 5-7 jam per hari & 111 & 38,95 \\
\hline$\geq 8$ jam per hari & 174 & 61,05 \\
\hline \multicolumn{3}{|l|}{ Pendapatan keluarga } \\
\hline$<\operatorname{Rp} 4.000 .000,-$ & 132 & 46,32 \\
\hline$\geq \operatorname{Rp} 4.000 .000,-$ & 153 & 53,68 \\
\hline \multicolumn{3}{|c|}{ Pendapatan ibu terhadap pendapatan keluarga } \\
\hline$<50 \%$ & 145 & 49,12 \\
\hline$\geq 50 \%$ & 140 & 50,88 \\
\hline \multicolumn{3}{|l|}{ Struktur keluarga } \\
\hline Inti & 183 & 64,21 \\
\hline Besar & 102 & 35,79 \\
\hline \multicolumn{3}{|l|}{ Status pekerjaan ayah } \\
\hline Bekerja & 243 & 85,26 \\
\hline Tidak bekerja & 10 & 3,51 \\
\hline Ibu sebagai orang tua tunggal & 32 & 11,23 \\
\hline \multicolumn{3}{|l|}{ Keberadaan asisten rumah tangga } \\
\hline Ya & 133 & 46,67 \\
\hline Tidak & 152 & 53,33 \\
\hline \multicolumn{3}{|l|}{ Preferensi makanan keluarga } \\
\hline Halal & 158 & 55,44 \\
\hline Tidak berpantang & 127 & 44,56 \\
\hline
\end{tabular}


Almira Sitasari, dkk: Konflik peran kerja-keluarga pada ibu bekerja terhadap perilaku obesogenis anak sekolah dasar

Tabel 2. Hubungan konflik peran kerja-keluarga pada ibu bekerja dengan perilaku obesogenis pada anak

\begin{tabular}{|c|c|c|c|c|c|c|c|}
\hline \multirow[b]{2}{*}{$\begin{array}{c}\text { Konflik peran } \\
\text { kerja-keluarga }\end{array}$} & \multicolumn{2}{|c|}{ Perilaku obesogenis } & \multirow[b]{2}{*}{$\begin{array}{c}\text { Jumlah } \\
\text { n (\%) }\end{array}$} & \multirow[b]{2}{*}{$\chi^{2}$} & \multirow[b]{2}{*}{ PR } & \multirow[b]{2}{*}{$95 \%$ CI } & \multirow[b]{2}{*}{$\mathbf{p}$} \\
\hline & $\begin{array}{l}\text { Tinggi } \\
\text { n (\%) }\end{array}$ & $\begin{array}{c}\text { Rendah } \\
\text { n (\%) }\end{array}$ & & & & & \\
\hline Tinggi & $81(47,65)$ & $89(52,35)$ & $170(100 \%)$ & 0,96 & 0,79 & $0,49-1,27$ & 0,33 \\
\hline Rendah & $48(41,74)$ & $67(58,26)$ & $115(100 \%)$ & & 1,00 & & \\
\hline
\end{tabular}

Tabel 3. Tabulasi silang antara konflik peran kerja-keluarga pada ibu bekerja (quartil 1-4) dengan perilaku obesogenis anak

\begin{tabular}{cccccccc}
\hline $\begin{array}{c}\text { Kelompok skor } \\
\text { konflik peran } \\
\text { kerja-keluarga }\end{array}$ & $\begin{array}{c}\text { Terilaku obesogenis } \\
\text { n (\%) }\end{array}$ & $\begin{array}{c}\text { Rendah } \\
\text { n (\%) }\end{array}$ & $\begin{array}{c}\text { Jumlah } \\
\text { n (\%) }\end{array}$ & $\boldsymbol{\chi}^{\mathbf{2}}$ & PR & $\mathbf{9 5 \%}$ CI & p \\
\cline { 2 - 6 } Quartil 1 & $17(38,64)$ & $27(61,36)$ & $44(100)$ & - & 1,00 & - & - \\
Quartil 2 $^{\text {b }}$ & $31(43,66)$ & $40(56,34)$ & $71(100)$ & 0,28 & 0,81 & $0,38-1,76$ & 0,60 \\
Quartil 3 $^{\text {c }}$ & $16(47,06)$ & $18(52,94)$ & $34(100)$ & 0,55 & 0,71 & $0,28-1,77$ & 0,46 \\
Quartil 4 $^{\text {d }}$ & $65(47,79)$ & $71(52,21)$ & $136(100)$ & 1,12 & 0,69 & $0,34-1,38$ & 0,29 \\
\hline
\end{tabular}

Keterangan: ${ }^{\mathrm{a}}$ Quartil 1 = skor konflik peran $0-1$; ${ }^{\mathrm{b}}$ Quartil 2 = skor konflik peran 2-3;

${ }^{\mathrm{c}}$ Quartil 3= skor konflik peran 4; ${ }^{\mathrm{d}}$ Quartil $4=$ skor konflik peran $\geq 5$

Tabel 4. Tabulasi silang konflik peran kerja-keluarga pada ibu bekerja menurut perilaku obesogenis faktor 1-4

\begin{tabular}{|c|c|c|c|c|c|c|}
\hline \multirow{2}{*}{$\begin{array}{c}\text { Konflik peran } \\
\text { kerja-keluarga }\end{array}$} & \multicolumn{2}{|c|}{ Perilaku obesogenis } & \multirow{2}{*}{$\begin{array}{c}\text { Jumlah } \\
\text { n (\%) }\end{array}$} & \multirow[b]{2}{*}{$\chi^{2}$} & \multirow[b]{2}{*}{ PR (CI) } & \multirow[b]{2}{*}{$\mathbf{p}$} \\
\hline & $\begin{array}{l}\text { Tinggi } \\
\text { n }(\%) \\
\end{array}$ & $\begin{array}{c}\text { Rendah } \\
\text { n }(\%)\end{array}$ & & & & \\
\hline \multicolumn{7}{|c|}{ Perilaku obesogenis } \\
\hline \multicolumn{7}{|c|}{ Faktor 1 (perilaku orang tua) } \\
\hline Tinggi & $74(43,53)$ & $96(56,47)$ & $170(100)$ & 0,00 & $0,99(0,62-1,61)$ & 0,99 \\
\hline Rendah & $50(43,48)$ & $65(56,52)$ & $115(100)$ & & $1,00(-)$ & \\
\hline \multirow{2}{*}{\multicolumn{7}{|c|}{$\begin{array}{l}\text { Perilaku obesogenis } \\
\text { Faktor } 2 \text { (aktivitas fisik) }\end{array}$}} \\
\hline & & & & & & \\
\hline Tinggi & $87(51,18)$ & $83(48,82)$ & $170(100)$ & 1,28 & $0,76(0,47-1,23)$ & 0,26 \\
\hline Rendah & $51(44,35)$ & $64(55,65)$ & $115(100)$ & & $1,00(-)$ & \\
\hline \multicolumn{7}{|c|}{ Perilaku obesogenis } \\
\hline \multicolumn{7}{|c|}{ Faktor 3 (rutinitas waktu makan) } \\
\hline Tinggi & $71(41,76)$ & $99(58,24)$ & $170(100)$ & 0,20 & $0,90(0,69-1,81)$ & 0,66 \\
\hline Rendah & $45(39,13)$ & $70(60,87)$ & $115(100)$ & & $1,00(-)$ & \\
\hline \multicolumn{7}{|c|}{$\begin{array}{l}\text { Perilaku obesogenis } \\
\text { Faktor } 4 \text { (perilaku makan anak) }\end{array}$} \\
\hline Tinggi & $72(42,35)$ & $98(57,65)$ & $170(100)$ & 0,11 & $1,08(0,67-1,75)$ & 0,74 \\
\hline Rendah & $51(44,35)$ & $64(55,65)$ & $115(100)$ & & $1,00(-)$ & \\
\hline
\end{tabular}

Berdasarkan Tabel 2 diketahui bahwa tidak terdapat hubungan antara konflik peran kerja-keluarga pada ibu bekerja dengan perilaku obesogenis anak. Sementara itu, Tabel 3 menunjukkan bahwa tren skor konflik peran menurut perilaku obesogenis menunjukkan kecenderungan yang menurun. Dari hasil prevalence ratio (PR) yang didapatkan, diketahui bahwa semakin meningkat skor konflik peran maka semakin menurun kemungkinan untuk berperilaku obesogenis tinggi. Secara statistik, hubungan tersebut tidak signifikan tetapi dapat menunjukkan tren skor konflik dan hubungannya dengan perilaku obesogenis. Hal ini berlawanan dengan teori yang ada selama ini bahwa konflik peran kerja-keluarga yang tinggi umumnya mengurangi output kepuasan dalam keluarga dan mengakibatkan kepuasan pola asuh orang tua yang rendah pada keluarga $(13,14)$. 
Almira Sitasari, dkk: Konflik peran kerja-keluarga pada ibu bekerja terhadap perilaku obesogenis anak sekolah dasar

Tabel 5. Hasil analisis variabel lain yang memiliki potensi berpengaruh dengan perilaku obesogenis pada anak

\begin{tabular}{|c|c|c|c|c|c|c|c|}
\hline \multirow[b]{2}{*}{ Variabel } & \multicolumn{2}{|c|}{ Perilaku obesogenis } & \multirow[b]{2}{*}{$\begin{array}{c}\text { Jumlah } \\
\text { n (\%) }\end{array}$} & \multirow[b]{2}{*}{$\chi^{2}$} & \multirow[b]{2}{*}{ PR } & \multirow[b]{2}{*}{$95 \% \mathrm{CI}$} & \multirow[b]{2}{*}{$\mathbf{p}$} \\
\hline & $\begin{array}{l}\text { Tinggi } \\
\text { n (\%) }\end{array}$ & $\begin{array}{c}\text { Rendah } \\
\text { n (\%) }\end{array}$ & & & & & \\
\hline \multicolumn{8}{|l|}{ Jenis kelamin } \\
\hline Laki-laki & $51(38,64)$ & $81(61,36)$ & $132(100)$ & 4,34 & 1,65 & $1,03-2,66$ & 0,03 \\
\hline Perempuan & $78(50,98)$ & $75(49,02)$ & $153(100)$ & & 1,00 & & \\
\hline \multicolumn{8}{|l|}{ Jumlah anak } \\
\hline$\geq 2$ & $38(41,30)$ & $54(58,70)$ & $92(100)$ & 0,86 & 1,27 & $0,77-2,10$ & 0,35 \\
\hline 1 & $91(47,15)$ & $102(52,85)$ & $193(100)$ & & 1,00 & & \\
\hline \multicolumn{8}{|l|}{ Status gizi } \\
\hline Kurus-normal & $71(40,80)$ & $103(59,20)$ & $174(100)$ & 3,57 & 1,59 & $0,98-2,57$ & 0,06 \\
\hline Gizi lebih-obes & $58(52,25)$ & $53(47,75)$ & $111(100)$ & & 1,00 & & \\
\hline \multicolumn{8}{|l|}{ Pendapatan keluarga } \\
\hline$<\operatorname{Rp} 4.000 .000,-$ & $57(37,25)$ & $96(62,75)$ & $153(100)$ & 8,52 & 2,02 & $1,25-3,27$ & $<0,001$ \\
\hline$\geq \operatorname{Rp} 4.000 .000,-$ & $72(54,55)$ & $60(45,45)$ & $132(100)$ & & 1,00 & & \\
\hline \multicolumn{8}{|l|}{ Struktur keluarga } \\
\hline Besar & $42(41,18)$ & $60(58,82)$ & $102(100)$ & 1,07 & 1,29 & $0,79-2,12$ & 0,30 \\
\hline Inti & $87(47,54)$ & $96(52,46)$ & $183(100)$ & & 1,00 & & \\
\hline \multicolumn{8}{|l|}{ Status pekerjaan ayah } \\
\hline Bekerja & $108(44,44)$ & $135(55,56)$ & $243(100)$ & 0,44 & 1,25 & $0,65-2,41$ & 0,50 \\
\hline Tidak bekerja & $21(50)$ & $21(50)$ & $42(100)$ & & 1,00 & & \\
\hline \multicolumn{8}{|l|}{ Keberadaan asisten rumah tangga } \\
\hline Ya & $54(40,60)$ & $79(59,40)$ & $133(100)$ & 2,18 & 1,42 & $0,89-2,29$ & 0,14 \\
\hline Tidak & $75(49,34)$ & $77(50,66)$ & $152(100)$ & & 1,00 & & \\
\hline \multicolumn{8}{|l|}{ Preferensi makanan keluarga } \\
\hline Halal & $65(41,14)$ & $93(58,86)$ & $158(100)$ & 2,43 & 1,45 & $0,91-2,33$ & 0,12 \\
\hline Tidak berpantang & $64(50,39)$ & $63(49,61)$ & $127(100)$ & & 1,00 & & \\
\hline \multicolumn{8}{|l|}{ Pendidikan ibu } \\
\hline Tinggi & $77(39,90)$ & $116(60,10)$ & $193(100)$ & 6,93 & 1,96 & $1,17-3,26$ & $<0,001$ \\
\hline Menengah & $52(56,52)$ & $40(43,48)$ & $92(100)$ & & 1,00 & & \\
\hline \multicolumn{8}{|l|}{ Tempat bekerja ibu } \\
\hline Dalam rumah & $9(37,50)$ & $15(62,50)$ & $24(100)$ & 0,64 & 1,42 & $0,60-3,37$ & 0,43 \\
\hline Luar rumah & $120(45,26)$ & $141(54,02)$ & $261(100)$ & & 1,00 & & \\
\hline \multicolumn{8}{|l|}{ Posisi pekerjaan ibu } \\
\hline Profesional dan manajerial & $70(39,11)$ & $109(60,89)$ & $179(100)$ & 7,34 & 1,95 & $1,19-3,20$ & $<0,001$ \\
\hline Teknis & $59(55,66)$ & $47(44,34)$ & $106(100)$ & & 1,00 & & \\
\hline \multicolumn{8}{|l|}{ Lama bekerja per hari } \\
\hline$\geq 8$ jam & $79(45,40)$ & $95(54,60)$ & $174(100)$ & 0,00 & 0,99 & $0,61-1,59$ & 0,95 \\
\hline $5-7$ jam & $50(45,05)$ & $61(54,95)$ & $111(100)$ & & 1,00 & & \\
\hline
\end{tabular}

Perilaku obesogenis yang diobservasi dalam penelitian ini terdiri dari 4 kategori perilaku yaitu faktor 1 (perilaku orang tua), faktor 2 (aktivitas fisik), faktor 3 (rutinitas waktu makan), dan faktor 4 (perilaku makan anak) (8). Selanjutnya dalam Tabel 4 disajikan tabulasi silang antara masing-masing dari keempat faktor tersebut dengan konflik peran.

Hasil penelitian (Tabel 4) menunjukkan bahwa tidak terdapat faktor yang berhubungan dengan konflik peran kerja-keluarga yang signifikan secara statistik. Namun, rasio prevalensi (PR) dari hasil analisis keempat faktor tersebut juga menunjukkan bahwa konflik peran kerja-keluarga ibu yang tinggi akan menurunkan risiko anak untuk berperilaku obesogenis rendah untuk faktor perilaku orang tua, aktivitas fisik anak, dan rutinitas waktu makan. Sementara itu, ibu dengan konflik peran kerja yang tinggi akan meningkatkan risiko anak untuk berperilaku obesogenis yang tinggi pula pada faktor perilaku makan anak. 


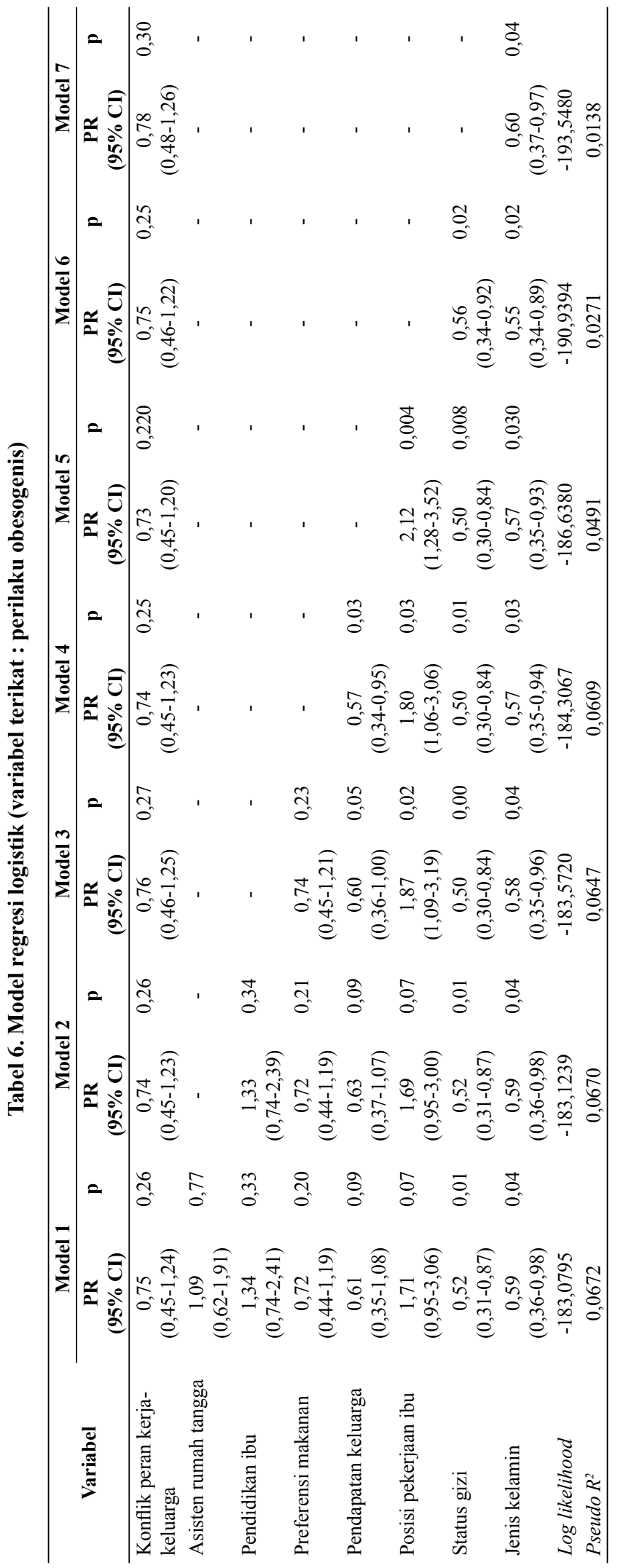

Komparabilitas atau perbandingan variabel lain yang berpengaruh terhadap perilaku obesogenis disajikan pada Tabel 5. Diketahui terdapat beberapa variabel yang berpotensi ikut mempengaruhi hasil tidak adanya hubungan antara konflik peran kerja-keluarga terhadap perilaku obesogenis pada anak yaitu jenis kelamin, status gizi, pendapatan keluarga, adanya asisten rumah tangga, preferensi makanan, pendidikan ibu, dan posisi pekerjaan ibu $(p<0,25)$ yang untuk mengetahuinya kemudian dianalisis secara multivariat.

Analisis multivariat untuk menilai hubungan antara perilaku obesogenis dan variabel lain secara bersamaan dilakukan dengan analisis regresi logistik. Teknik yang digunakan adalah backward stepwise regression yaitu dengan memasukkan semua variabel yang penting atau yang memiliki nilai kemaknaan (p) kurang dari 0,25 dari uji bivariat ke dalam model, kemudian dikeluarkan satu persatu berdasarkan kriteria nilai $p$ lebih dari 0,05 dimulai dari variabel dengan nilai p terbesar. Berdasarkan hasil analisis multivariat, diperoleh bahwa pendapatan keluarga, posisi pekerjaan ibu, status gizi, dan jenis kelamin pada anak merupakan effect modifier dalam penelitian (Tabel 6). Diketahui dari hasil penelitian bahwa anak yang berisiko memiliki perilaku obesogenis tinggi, banyak ditemukan pada anak dengan ibu yang memiliki tingkat sosial ekonomi tinggi yaitu pada ibu dengan pendapatan keluarga tinggi, pendidikan tinggi, dan memiliki pekerjaan manajerial atau profesional. Hasil analisis juga menunjukkan bahwa pendidikan ibu, status pekerjaan ayah, dan status gizi bukan merupakan variabel penggangu (confounding factors) karena perbedaan taksiran crude PR dan adjustment PR kecil $(\triangle \mathrm{PR}<10 \%)$.

\section{BAHASAN}

Hasil analisis bivariat menunjukkan bahwa tidak terdapat hubungan antara konflik peran kerja-keluarga pada ibu bekerja terhadap perilaku obesogenis anak. Hasil analisis skor konflik peran dengan cut-off berdasarkan quartil 1-4 juga menunjukkan tidak adanya hubungan dengan perilaku obesogenis. Walaupun demikian, hasil ini dapat menunjukkan tren skor konflik peran kerja menurut skor perilaku obesogenis yang menunjukkan 
kecenderungan bahwa semakin tinggi perilaku konflik peran kerja-keluarga pada ibu bekerja semakin rendah risiko anak berperilaku obesogenis. Hasil ini dapat dijelaskan dengan berbagai kemungkinan.

Kemungkinan pertama adalah adanya pengaruh kelompok umur anak subjek penelitian. Pada kelompok anak usia sekolah, perilaku anak dipengaruhi oleh halhal yang lebih luas dibandingkan dengan kelompok anak usia yang lebih muda atau anak prasekolah yang masih sangat bergantung pada orang tuanya sehingga juga mempengaruhi konsumsi makanannya (15). Anak usia sekolah sudah lebih mandiri sehingga perilaku makan dan aktivitas fisik yang dilakukannya banyak dipengaruhi oleh teman-teman sebayanya (16). Selain itu, anak sekolah juga mulai banyak bersosialisasi dengan lingkungan yang lebih luas di luar keluarga sehingga perilaku makan dan aktivitasnya juga dipengaruhi lingkungan, sekolah, media, industri makanan, dan lain-lain. Diketahui bahwa dorongan sosial dari teman sebaya dan saudara memainkan peranan penting dalam meningkatkan aktivitas fisik anak usia sekolah (17) dan mereka yang melibatkan saudara atau teman sebayanya, memiliki kecenderungan 3-4 kali lebih aktif dibandingkan anak yang hanya melibatkan orang tua mereka (18). Hal ini penting diketahui, mengingat peran sosial dalam pembentukan perilaku anak pada anak usia sekolah sangatlah besar. Di Indonesia khususnya di Kota Yogyakarta, kelompok ekstrakurikuler olahraga sangat banyak ditemukan sehingga jika dikaitkan dengan alasan pertama, dukungan sosial seperti ini sangat membantu orang tua khususnya ibu bekerja dalam penerapan hidup sehat pada anak tanpa harus melibatkan orang tua sendiri dalam kegiatan tersebut.

Kemungkinan kedua adalah adanya beberapa kelemahan penelitian yang dinilai dapat mempengaruhi hasil observasi. Dalam penelitian cross-sectional yang menggunakan suatu instrumen kuesioner, daya ingat responden (ibu bekerja) terkadang menjadi kendala dalam memberikan jawaban yang sesuai dengan kenyataan, terlebih pada penelitian yang terkait dengan kebiasaan atau perilaku. Selain itu, status gizi mempengaruhi akurasi pelaporan konsumsi makan oleh anak maupun orang tua (19) sehingga tidak menutup kemungkinan juga bahwa dalam penelitian ini, ibu dengan anak yang gemuk dan berperilaku obesogenis tinggi, melaporkan lebih sedikit konsumsi makanan obesogenis dan sebaliknya. Begitu juga dengan butir pernyataan mengenai aktivitas fisik atau perilaku obesogenis lainnya. Oleh karena banyaknya butir pernyataan dalam kuesioner Family Health Behavior Scale yang memuat mengenai perilaku orang tua, memungkinkan ibu bekerja sebagai responden mengisikan jawaban sesuai dengan norma yang benar, bukan kenyataan yang sebenarnya (8) sehingga hal ini juga dapat mempengaruhi hasil akhir penelitian.

Tidak adanya hubungan antara kedua variabel penelitian dapat juga disebabkan oleh adanya variabel lain dalam penelitian yang ikut mempengaruhi hasil penelitian. Dari hasil analisis multivariat, diperoleh bahwa pendapatan keluarga, posisi pekerjaan ibu, status gizi, dan jenis kelamin pada anak merupakan effect modifier dalam penelitian. Anak yang berisiko memiliki perilaku obesogenis tinggi, lebih banyak ditemukan pada anak dengan tingkat sosial ekonomi ibu yang tinggi yaitu ibu dengan pendapatan keluarga tinggi, pendidikan tinggi, dan memiliki pekerjaan manajerial atau profesional.

Pendapatan keluarga sangat terkait dengan keberadaan akses pada berbagai macam makanan tinggi kalori atau fasilitas yang memungkinkan anak untuk tidak melakukan banyak aktivitas (20). Hasil penelitian ini menunjukkan bahwa anak dari keluarga berpenghasilan tinggi memiliki risiko 2,02 kali untuk berperilaku obesogenis tinggi dibandingkan dengan anak dari keluarga berpenghasilan rendah. Hal ini sejalan dengan teori yang menyatakan bahwa secara kontekstual, obesitas yang terjadi di wilayah Asia terutama disebabkan oleh urbanisasi yang sejalan beriringan dengan meningkatnya pendapatan penduduk (21).

Sementara itu, posisi atau jenis pekerjaan ibu berkaitan dengan beban yang ditanggung dalam pekerjaan sehingga dapat mempengaruhi stres. Stres inilah yang mempengaruhi seorang ibu bekerja untuk tidak dapat memenuhi seluruh perannya dalam membiasakan perilaku hidup sehat bagi anaknya (22). Anak dengan ibu yang memiliki pekerjaan profesional dan manajerial berisiko 1,95 kali untuk berperilaku obesogenis dibandingkan anak dengan ibu yang bekerja teknis. Jenis pekerjaan yang dimiliki seseorang dapat menjadi kendala dalam menjalankan perannya dalam pekerjaan dan keluarga. 
Konflik peran kerja dan keluarga banyak dialami oleh orang yang bekerja dalam bidang manajerial. Selanjutnya, hal ini dapat dijelaskan bahwa faktor interdependensi dan tanggung jawab dengan orang lain adalah salah satu faktor yang mempengaruhi konflik peran-kerja-keluarga karena pengaruhnya dalam stres seseorang dapat menyebabkan fatigue, yang kemudian mengganggu hubungan seseorang dengan orang lain atau tidak terpenuhinya peran lain dalam hal ini peran dalam keluarga (23).

Hasil analisis juga menunjukkan bahwa anak dengan status gizi kurang-normal memiliki risiko 1,59 kali lebih besar untuk berperilaku obesogenis tinggi dibandingkan anak dengan status gizi lebih-obesitas. Hal ini bertentangan dengan teori bahwa asupan makanan dan perilaku makan obesogenis (21) serta aktivitas fisik yang rendah berhubungan dengan risiko obesitas yang tinggi (24). Hal ini dapat dijelaskan dengan pendekatan penelitian cross sectional, yaitu anak yang sudah bermanifestasi menderita gizi lebih atau obesitas cenderung sudah lebih membatasi makanan yang bersifat obesogenis atau sudah meningkatkan aktivitas fisik dibandingkan anak dengan yang status gizi normal atau lebih. Hal yang hampir sama juga terjadi pada penelitian mengenai media yang menemukan bahwa paparan iklan akan lebih meningkatkan preferensi pemilihan makanan bermerk yang bersifat obesogenis pada anak dengan status gizi normal dibandingkan dengan anak berstatus gizi lebih atau obesitas (25). Penelitian yang dilakukan di Australia mengungkapkan bahwa anak yang cenderung mengalami gizi lebih dan overweight cenderung tidak memiliki kepuasan terhadap bentuk tubuhnya (26) sehingga dimungkinkan untuk juga mempengaruhi perilaku obesogenis oleh anak.

Lebih lanjut, diketahui bahwa anak laki-laki 1,65 kali lebih berisiko berperilaku obesogenis dibandingkan dengan anak perempuan. Hal ini kemungkinan terjadi karena adanya perbedaan perilaku terhadap body image antara anak laki-laki dan perempuan sehingga juga mempengaruhi perilaku obesogenis yang diadopsi dalam kehidupan. Hal ini juga ditemukan dalam penelitian di Inggris yang dilakukan pada anak-anak etnis Asia Selatan, yang mengungkapkan bahwa anak perempuan lebih memperhatikan bentuk tubuhnya dibandingkan anak lakilaki (27). Perilaku makan yang bersifat obesogenis juga ditemukan pada penelitian di 9 negara di Eropa dengan subjek anak usia sekolah yang menyatakan bahwa anak perempuan secara signifikan lebih banyak mengonsumsi sayur dan buah dibandingkan anak laki-laki (28). Namun, menurut penelitian yang dilakukan di Amerika, anak lakilaki lebih banyak melakukan aktivitas fisik dibandingkan perempuan pada kelompok usia 9-15 tahun. Bahkan, anak perempuan diketahui tidak memenuhi rekomendasi aktivitas fisik sedang-berat sebanyak 60 menit per hari (29). Dengan demikian, perilaku obesogenis menurut jenis kelamin sangat bervariasi menurut jenis perilaku obesogenisnya. Selain itu, error measurement yang menyebabkan bias secara sistematik juga dimungkinkan dalam penelitian ini karena kedua kuesioner sama-sama diisikan oleh ibu bekerja sehingga sangat rentan untuk menghasilkan bias informasi.

\section{SIMPULAN DAN SARAN}

Berdasarkan hasil penelitian ini dapat disimpulkan bahwa tidak ada pengaruh konflik peran kerja-keluarga terhadap perilaku obesogenis anak sekolah dasar di Kota Yogyakarta. Variabel yang berpengaruh terhadap perilaku obesogenis anak antara lain pendapatan keluarga, posisi atau jenis pekerjaan ibu, status gizi anak, dan jenis kelamin anak. Oleh karena itu, diperlukan edukasi dan promosi mengenai pola asuh yang dapat menurunkan risiko anak berperilaku obesogenis terutama pada ibu bekerja dengan tingkat sosial ekonomi tinggi. Selain itu, diperlukan promosi kesehatan oleh tenaga kesehatan pada sekolah dasar yang berada dalam wilayah kerjanya agar dapat menciptakan lingkungan sehat dan leptogenis misalnya dengan memperbanyak kegiatan berbasis aktivitas fisik dan pengawasan makanan berkalori tinggi yang dijual di wilayah sekolah pada kelompok anak berisiko maupun yang sudah mengalami kegemukan.

\section{RUJUKAN}

1. Usfar AA, Lebenthal E, Atmarita, Achadi E, Soekirman, Hadi H. Obesity as a poverty-related emerging nutrition problems: the case of Indonesia. Obes Rev 2010;11(12):924-8.

2. Balai Penelitian dan Pengembangan Kesehatan, Departemen Kesehatan Republik Indonesia. Riset Kesehatan Dasar 2007. Jakarta: Departemen Kesehatan; 2008. 
3. Ornelas IJ, Perreira KM, Ayala GX. Parental influences on adolescent physical activity: a longitudinal study. Int $\mathrm{J}$ Behav Nutr Phys Act 2007;4:3.

4. Möser A, Chen SE, Jilcott SB, Nayga RM. Associations between maternal employment and time spent in nutritionrelated behaviours among German children and mothers. Public Health Nutr 2012;15(7):1256-61.

5. Mitsuhashi T, Suzuki E, Takao S, Doi H. Maternal working hours and early childhood overweight in Japan: a population-based study. J Occup Health 2012;54(1):2533.

6. Wang Y. Cross-national comparison of childhood obesity: the epidemic and the relationship between obesity and socioeconomic status. Int J Epidemiol 2001;30(5):112936.

7. Mushtaq MU, Gull S, Shahid U, Shafique MM, Abdullah HM, Shad MA, Siddiqui AM. Family-based factors associated with overweight and obesity among Pakistani school children. BMC Pediatrics 2011;11:114.

8. Moreno JP, Kelley ML, Landry DN, Paasch V, Terlecki MA, Johnston CA, Foreyt JP. Development and validation of the family health behaviour scale. Int J Pediatr Obes 2011;6(2-2):e480-6.

9. Lemeshow S, Lwanga SK. Sample size determination in health studies. Geneva: World Health Organization; 1991.

10. Taylor AW, Winefield H, Kettler L, Roberts R, Gill TK. A population study of 5 to 15 years old: full time maternal employment not associated with high BMI. The importance of screen-based activity, reading for pleasure and sleep duration in children's BMI. Matern Child Health J 2012;16(3):587-99.

11. Netemeyer RG, Boles JS, McMurrian R. Development and validation of work-family conflict and family-work conflict scales. Journal of Applied Psychology 1996;81(4):40010.

12. WHO. Growth reference data for 5-19 years. [series online] 2007 [cited 2011 Des 11]. Available from: URL: http.// www.who.int

13. Ahmad A. Associations of work-family conflict, job satisfaction, family satisfaction, and life satisfaction: a study of married female secretaries. Pertanika J Soc Sci \& Hum 1996;4(2):101-8.

14. Shreffler KM, Meadows MP, Davis KD. Firefighting and fathering: work-family conflict, parenting stress, and satisfaction with parenting and child behaviour. Fathering 2011;9(2):169-88.

15. Koivisto Hursti, UK. Factors influencing children's food choice. Ann Med 1999;31(Suppl 1):26-32.

16. Salvy SJ, de la Haye K, Bowker JC, Hermans RC. Influence of peers and friends on children's and adolescents' eating and activity behaviors. Physiol Behav 2012;106(3):36978.

17. Martín-Matillas M, Ortega FB, Ruiz JR, Martínez-Gómez D, Marcos A, Moliner-Urdiales D, Polito A, PedreroChamizo R, Béghin L, Molnár D, Kafatos A, Moreno LA, De Bourdeaudhuij I, Sjöström M; HELENA study. Adolescent's physical activity levels and relatives' physical activity engagement and encouragement: the HELENA Study. Eur J Public Health 2011;21(6):705-12.

18. Seabra AF, Mendonça DM, Thomis MA, Malina RM, Maia JA. Correlates of physical activity in Portuguese adolescents from 10 to 18 years. Scand J Med Sci Sports 2011;21(2):318-23.

19. Fisher JO, Johnson RK, Lindquist C, Birch LL, Goran MI. Influence of body composition on the accuracy of reported energy intake in children. Obes Res 2000;8(8):597-603.

20. Merchant AT, Dehghan M, Bhenke-Cook D, Anand SS. Diet, physical activity, and adiposity in children in poor and rich neighbourhoods: a cross-sectional comparison. Nutr J 2007;6:1.

21. Guldan GS. Asian children's obesogenic diets-time to change this part of energi balance equation? Res Sports Med 2010;18(1):5-15.

22. Chung L, Wong T, Chung JW. Importance of balanced diet on the physical fitness level of scholchildren aged 6-12. J Child Health Care 2010;14(3):280-95.

23. Dierdorff EC, Ellington JK. It's the nature of the work: examining behavior-based sources of work-family conflict across occupation. J Appl Psychol 2008;93(4):883-92.

24. Han JC, Lawlor DA, Kimm SY. Childhood obesity. Lancet 2010;375(9727):1737-48.

25. Halford JC, Boyland EJ, Cooper GD, Dovey TM, Smith CJ, Williams N, Lawton CL, Blundell JE. Children's food preferences: effects of weight status, food type, branding and television food advertisements (commercials). Int $\mathbf{J}$ Pediatr Obes 2008;3(1):31-8.

26. Ricciardelli LA, McCabe MP. Children's body image concerns and eating disturbance: a review of the literature. Clin Psychol Rev 2001;21(3):325-44.

27. Pallan MJ, Hiam LC, Duda JL, Adab P. Body image, body dissatisfaction and weight status in south asian children: a cross-sectional study. BMC Public Health 2011;11:21.

28. Klepp KI, Rodrigo CP, Thorsdottir I, Due P, de Almeida MDV, Elmadfa I, Wolf A, Haraldsdóttir J, Brug J, Sjöström M, Yngve A, De Bourdeadhuij I. Promoting and sustaining health through increased vegetable and fruit consumption among European schoolchildren: The Pro Children Project. J Public Health 2005;13:97-101.

29. Nader PR, Bradley RH, Houts RM, McRitchie SL, O'Brien M. Moderate-to-vigorous physical activity from ages 9 to 15 years. JAMA 2008;300(3):295-305. 